\title{
PENGARUH PEMBERIAN JUS SEMANGKA TERHADAP PENURUNAN TEKANAN DARAH PADA LANSIA PENDERITA HIPERTENSI DI WILAYAH KERJA PUSKESMAS LUBUK BUAYA PADANG TAHUN 2017
}

\author{
Rebbi Permata Sari ${ }^{1}$, Ledia Restipa ${ }^{2}$, Marsia Yonira Putri ${ }^{3}$ \\ ${ }^{1}$ STIKes Alifah, Padang 25000 \\ Email: rebbi.permatasari@gmail.com \\ Email: ledia_restipa@yahoo.com \\ Email: marsiapuput05@gmail.com \\ ${ }^{2}$ Sekolah Tinggi Ilmu Keperawatan Alifah Padang \\ Email: stikes_alifah@yahoo.com
}

\begin{abstract}
ABSTRAK
Penelitian ini bertujuan untuk mengetahui pengaruh pemberian jus semangka terhadap penurunan tekanan darah pada lansia penderita hipertensi di wilayah kerja Puskesmas Lubuk Buaya Padang Tahun 2017

Jenis penelitian ini adalah Quasy Eksperimen dengan rancangan penelitian Two Group Pretest-Postest Design. Penelitian ini dilakukan di wilayah kerja Puskesmas Lubuk Buaya Padang Tahun 2017 pada bulan Januari-Agustus, pengumpulan data dilakukan selama 18 hari pada tanggal 03-20 Juli 2017. Populasi dari penelitian ini adalah semua lansia penderita hipertensi yang berkunjung di Puskesmas Lubuk Buaya Padang. Penarikan sampel dilakukan secara accidental sampling dengan jumlah sampel sebanyak 30 orang. Analisa data secara univariat dan bivariat menggunakan uji T-Tes Dependent. Rerata tekanan darah sistolik dan diastolik pretest pada kelompok intervensi adalah 174,00/96,67 mmHg dan pada kelompok kontrol adalah 169,33/96,67 mmHg. Rerata tekanan darah sistolik dan diastolik posttest pada kelompok intervensi adalah 156,00/82,00 mmHg dan pada kelompok kontrol adalah 167,33/93,33 mmHg. Ada pengaruh pemberian jus semangka terhadap penurunan tekanan darah pada lansia penderita hipertensi di wilayah kerja Puskesmas Lubuk Buaya Padang Tahun 2017

Dapat disimpulkan bahwa ada pengaruh pemberian jus semangka terhadap penurunan tekanan darah pada lansia penderita hipertensi. Diharapkan kepada perawat di Puskesmas Lubuk Buaya Padang untuk mensosialisasikan tentang manfaat buah semangka untuk menurunkan tekanan darah pada penderita hipertensi.
\end{abstract}

Kata Kunci: Jus Semangka, Lansia, Hipertensi

\section{ABSTRACT}

The prevalence of hypertension increased from year to year. Puskesmas Lubuk Buaya had the highest occurrence of hypertension on the elderly with 3614 cases. One way that could be done to control hypertension was to control blood pressure by drinking watermelon juice. The objective of the study was to find out the effect of watermelon juice on the blood pressure decline of the elderly sufferring from Hypertension in the work area of Puskesmas Lubuk Buaya Padang in 2017.

The type of the study was quasy-experimental with two-group pretest-posttest study design. The study was conducted in the work area of Puskesmas Lubuk Buaya Padang in 2017 from January to August. The data collecting was done in 18 days from July 3 to 20 2017. The populations of the study were all the elderly sufferring from hypertension and visiting Puskesmas Lubuk Buaya Padang. The sampling technique used was accidental sampling with the number of samples of 30 people. The data were analyzed by univariate and bivariate analysis using Dependent T-test.

The result of the study showed that the mean of systolic and diastolic blood pressure in pretest in the intervention group was 174,00/96,67 $\mathrm{mmHg}$, and in the control group was 169,33/96,67 $\mathrm{mmHg}$. The mean of systolic and diastolic blood pressure in posttest in the intervention group was 156,00/82,00 $\mathrm{mmHg}$, and in the control group was 167,33/93,33 $\mathrm{mmHg}$. From the result of the statistical test, it was found out that the p value was $0,000(p \leq 0,05)$, which meant that there was an effect of watermelon juice on the blood pressure decline of the elderly sufferring from Hypertension in the work area of Puskesmas Lubuk Buaya Padang in 2017.

There was an effect of watermelon juice on blood pressure decline of people sufferring from Hypertension. It is suggested that nurses of Puskesmas Lubuk Buaya Padang socialize the benefits of watermelon to lower blood pressure for people with hypertension.

Keywords : Watermelon juice, the elderly, hypertension. 


\section{PENDAHUluAN}

Salah satu indikator keberhasilan pembangunan adalah semakin meningkatnya Usia Harapan Hidup penduduk (UHH). Menurut World Health Organization (WHO) tahun 2013 di kawasan Asia Tenggara populasi lansia sebesar 8\% atau sekitar 142 juta jiwa. Pada tahun 2050 diperkirakan populasi lansia meningkat 3 kali lipat dari tahun sebelumnya. Pada tahun 2000 jumlah lansia sekitar 5.300.000 $(7,4 \%)$ dari total populasi, sedangkan pada tahun 2010 jumlah lansia meningkat menjadi 24.000.000 $(9,77 \%)$ dari total populasi. Pada tahun 2020 diperkirakan jumlah lansia mencapai 28.800.000 $(11,34 \%)$ (Kemenkes RI, 2015).

Menurut Kemenkes RI (2015) Indonesia termasuk dalam 5 besar negara dengan jumlah lanjut usia terbanyak di dunia. Pada tahun 2014, jumlah penduduk lanjut usia di Indonesia menjadi 18,781 juta jiwa dan diperkirakan pada tahun 2025, jumlahnya akan mencapai 36 juta jiwa. Indonesia memiliki 33 provinsi, salah satunya provinsi Sumatera Barat. Sumatera Barat menempati posisi ke 6 dengan penduduk lanjut usia terbanyak dari provinsi yang ada di Indonesia (Badan Pusat Statistik, 2014).

Menurut Badan Kependudukan dan Keluarga Berencana Nasional (BKKBN) 2015 dimana berdasarkan hasil pendataan keluarga yang dilakukan pada tahun 2015 terdapat 4.655.153 jiwa penduduk yang ada di Sumatera Barat. Dari hasil sensus tersebut, didapatkan jumlah lanjut usia di Sumatera Barat sebanyak 91.829 (19,72\%). Sumatera Barat memiliki 19 Kabupaten/Kota, salah satunya Kota Padang. Kota Padang memiliki angka tertinggi jumlah penduduk lanjut usia sebanyak 54.025 $(58,83 \%)$ (BKKBN, 2015).

Menurut Undang-Undang Nomor 13 tahun 1998 tentang Kesejahteraan Lanjut Usia, yang dimaksud dengan lanjut usia adalah penduduk yang telah mencapai usia 60 tahun ke atas (Maryam, 2011). Proses menua di dalam perjalanan hidup manusia merupakan suatu hal yang wajar yang akan dialami oleh semua orang yang dikaruniai umur panjang, proses ini terjadi terus-menerus dan berkelanjutan secara ilmiah (Nugroho, 2014). Masalah kesehatan pada lanjut usia berawal dari kemunduran sel-sel tubuh, sehingga fungsi dan daya tahan tubuh menurun serta faktor resiko terhadap penyakit pun meningkat.. Selain itu, beberapa penyakit yang sering terjadi pada lanjut usia antara lain, gangguan pendengaran, gangguan penglihatan, demensia, osteoporosis, dan hipertensi (Kemenkes RI, 2015).

Hipertensi berkaitan dengan kenaikan tekanan sistolik atau tekanan diastolik atau tekanan keduanya. Hipertensi dapat didefinisikan sebagai tekanan darah tinggi persistem dimana tekanan sistoliknya di atas $140 \mathrm{mmHg}$ dan tekanan diastolik di atas $90 \mathrm{mmHg}$. Pada populasi manula, hipertensi didefinisikan sebagai tekanan sistolik $160 \mathrm{mmHg}$ dan tekanan diastolik $90 \mathrm{mmHg}$ (Wijaya, 2013). Selain itu, perubahan pada perilaku dan gaya hidup pada masyarakat juga dapat menjadi salah satu penyebab penyakit hipertensi (Nisa, 2012).

Data Global Status Report on Noncommuncale Disease menyebutkan $40 \%$ negara berkembang memiliki penderita hipertensi, sedangkan negara maju hanya $35 \%$. Kawasan Afrika memegang posisi puncak penderita hipertensi sebanyak $46 \%$, kawasan Amerika menempati posisi sebanyak 36\%, dan Asia Tenggara sebanyak 35\% (Candra, 2016). Indonesia berada dalam deretan 10 negara dengan prevalensi hipertensi tertinggi di dunia, bersama Myanmar, India, Srilanka, Bhutan, Thailand, Nepal, dan Maldives (Anonim, 2013).

Menurut Riskesdas (2013) penderita hipertensi di Indonesia sebanyak 31,7\%. Hipertensi banyak terjadi pada usia lanjut yaitu usia 55-64 tahun sebanyak 45,9\%, usia 65-74 tahun sebanyak 57,6\%, dan usia $>76$ tahun sebanyak $63,8 \%$. Indonesia memiliki 33 provinsi, salah satunya provinsi Sumatera Barat. Sumatera Barat menempati posisi ke 20 dengan penderita hipertensi terbanyak dari provinsi yang ada di Indonesia.

Komplikasi hipertensi dapat diatasi dengan cara farmakologi dan non farmakologi. Menurut Purwanto (2014) pengobatan non farmakologi dapat diobati dengan menggunakan pengobatan herbal. Perkembangan konsep herbal dalam dunia keperawatan tidak terlepas dari peran Florence Nightingale. Penggunaan nutrisi bahan pangan alami (herbal) menjadi modal dasar dalam pembangunan kesehatan manusia secara sempurna, dimana penggunaan nutrisi alami (herbal) untuk menunjang terapi dalam hal pencegahan, pengobatan penyakit, dan perawatan kesehatan secara umum.

Menurut Arturo (2012) ada beberapa tanaman herbal yang digunakan untuk pengobatan seperti mentimun, bawang putih, labu siam, seledri, semangka, daun salam dan masih banyak buahbuahan atau sayuran lain yang bisa digunakan untuk pengobatan herbal. Salah satu buah-buahan yang dapat menurunkan tekanan darah adalah semangka, karena kandungan yang ada dalam obat anti hipertensi tersebut ada beberapa yang kita temui dalam semangka yaitu potassium, beta karoten, dan kalium. Semangka sangat kaya akan kandungan air, asam amino, L-arginine yang dapat menjaga tekanan darah yang sehat.

Asam amino sitrulin pada semangka digunakan oleh tubuh untuk memproduksi asam amino arginine, digunakan sel-sel pelapis pembuluh darah untuk membuat nitrat oksida. Nitrat oksida berfungsi untuk melemaskan pembuluh darah sehingga dapat menurunkan tekanan darah dan mencegah terjadinya penyakit jantung (Puspaningtyas, 2013).

Berdasarkan data Dinas Kesehatan Kota Padang tahun 2016, angka kejadian hipertensi pada lansia tertinggi terdapat di Puskesmas Lubuk Buaya. Puskesmas Lubuk Buaya menempati urutan pertama 
angka kejadian hipertensi pada lansia tertinggi sebanyak 3.614, urutan kedua terdapat di Puskesmas Padang Pasir sebanyak 2.988, dan urutan ketiga terdapat di Puskesmas Pauh sebanyak 2.389 (Dinas Kesehatan Kota Padang, 2016).

Puskesmas Lubuk Buaya merupakan salah satu Puskesmas di kota Padang. Angka kejadian hipertensi pada lansia di Puskesmas Lubuk Buaya meningkat setiap tahunnya, pada tahun 2014 sebanyak 405 orang, pada tahun 2015 sebanyak 1.141 orang, dan pada tahun 2016 sebanyak 3.614 orang (Profil Puskesmas Lubuk Buaya, 2016).

Berdasarkan survey awal yang dilakukan pada tanggal 30 -31 Januari 2017 di Puskesmas Lubuk Buaya terhadap 10 orang lansia dengan hipertensi didapatkan 3 diantaranya pernah melakukan terapi herbal dengan mengkonsumsi mentimun, 2 orang menggunakan terapi herbal labu siam, dan 2 orang lagi menggunakan terapi herbal seledri, serta 3 orang lainnya mengkonsumsi obat hipertensi dan tidak pernah mencoba terapi herbal untuk menurunkan tekanan darahnya. Dari hasil wawancara 10 orang lansia tersebut mereka mengatakan bosan minum obat penurun tekanan darah karena menimbulkan efek samping dan ketergantungan, apabila tidak minum obat tekanan darahnya tetap tinggi. Selain itu, memerlukan biaya yang tinggi karena pengobatan memerlukan jangka waktu yang lama dan biaya yang tidak sedikit diperlukan untuk mengatasi komplikasi yang mungkin timbul akibat penyakit hipertensi yang dideritanya. Karena berbagai alasan tersebut, mereka ingin mencoba pengobatan lain yang lebih ekonomis dan minim efek samping, seperti pengobatan herbal. Untuk penggunaan jus semangka mereka mengatakan belum mengetahui kalau jus semangka memiliki manfaat untuk menurunkan tekanan darah.

\section{METODA PENELITIAN}

Jenis penelitian kuantitatif dengan desain yang dipakai Quasi Eksperimen dengan rancangan penelitian yang digunakan adalah rancangan Two Group Pretest-Posttest Design Penelitian ini dilakukan di Wilayah Kerja Puskesmas Lubuk Buaya Padang tahun 2017, dengan wilayah kerja yang diambil yaitu Kelurahan Parupuak Tabing. Populasi dalam penelitian ini adalah semua lansia yang menderita hipertensi dan sampel sebanyak 30 orang, yang terdiri dari 15 orang kelompok intervensi dan 15 orang kelompok control dengan Accidental Sampling dengan kriteria inklusi Tekanan darah $\geq 160$ mmHgdan lansia usia 55-64 tahun. Pengolahan data melalui analisa data secara univariat dan bivariat menggunakan uji T-Tes Dependent

\section{III.HASIL}

\section{a. Analisa Univariat}

Analisis univariat digunakan untuk mengetahui rata-rata dari masing-masing variabel yang diteliti, bertujuan untuk menjelaskan atau mendiskripsikan karakteristik setiap variabel penelitian. Variabel independen adalah pemberian jus semangka dan variabel dependen adalah tekanan darah tinggi (hipertensi), sebagai mana terlihat pada tabel berikut ini :

1. Rerata Tekanan Darah Lansia sebelum diberikan Jus Semangka di Wilayah Kerja Puskesmas Lubuk Buaya Padang Tahun 2017 Tabel 1Rerata Tekanan Darah Lansia PreTest Kelompok Intervensi dan Kelompok Kontrol di Wilayah Kerja Puskesmas Lubuk Buaya Padang Tahun 2017

\begin{tabular}{lcccccc}
\hline Kelompok & $\begin{array}{c}\text { Tekanan } \\
\text { Dara } \\
\text { h }\end{array}$ & N & Mean & SD & Min & Max \\
\hline Intervensi & Sistolik & 15 & 174,00 & 7,368 & 160 & 190 \\
& Diastolik & 15 & 96,67 & 9,759 & 90 & 120 \\
\hline Kontrol & Sistolik & 15 & 169,33 & 9,612 & 160 & 190 \\
& & & & & & \\
\hline & Diastolik & 15 & 96,67 & 7,237 & 90 & 110 \\
& & & & & & \\
\hline
\end{tabular}

Berdasarkan tabel 1 diatas dapat dilihat bahwa rata-rata tekanan darah sistolik pretest pada kelompok intervensi adalah $174,00 \mathrm{mmHg}$ dengan standar deviasi 7,368 dan tekanan darah diastolik 96,67 $\mathrm{mmHg}$ dengan standar deviasi 9,759. Pada kelompok kontrol rata-rata tekanan darah sistolik pretest adalah $169,33 \mathrm{mmHg}$ dengan standar deviasi 9,612 dan tekanan darah diastolik 96,67 dengan standar deviasi 7,237.

2. Rerata Tekanan Darah Lansia sesudah diberikan Jus Semangka di Wilayah Kerja Puskesmas Lubuk Buaya Padang Tahun 2017

Tabel 2 Rerata Tekanan Darah Lansia PostTest Kelompok Intervensi dan Kelompok Kontrol di Wilayah Kerja Puskesmas Lubuk Buaya Padang Tahun 2017

\begin{tabular}{ccccccc}
\hline Kelompok & $\begin{array}{c}\text { Tekanan } \\
\text { Dar } \\
\text { ah }\end{array}$ & $\mathbf{N}$ & Mean & SD & Min & Max \\
\hline Intervensi & Sistolik & 15 & 156,00 & 5,071 & 150 & 160 \\
\hline & Diastolik & 15 & 82,00 & 4,140 & 80 & 90 \\
\hline Kontrol & Sistolik & 15 & 167,33 & 7,037 & 160 & 180 \\
& Diastolik & 15 & 93,33 & 4,880 & 90 & 100 \\
& & & & & & \\
\hline
\end{tabular}

Berdasarkan tabel 2 diatas dapat dilihat bahwa rata-rata tekanan darah sistolik posttest pada 
kelompok intervensi adalah 156,00 $\mathrm{mmHg}$ dengan standar deviasi 5,071 dan tekanan darah diastolik $82,00 \mathrm{mmHg}$ dengan standar deviasi 4,140. Pada kelompok kontrol rata-rata tekanan darah sistolik posttest adalah $167,33 \mathrm{mmHg}$ dengan standar deviasi 7,037 dan tekanan darah diastolik 93,33 $\mathrm{mmHg}$ dengan standar deviasi 4,880.

\section{b. Analisis Bivariat}

Analisisa bivariat bertujuan untuk melihat adanya pengaruh pemberian jus semangka terhadap penurunan tekanan darah pada lansia penderita hipertensi di Wilayah Kerja Puskesmas Lubuk Buaya Padang Tahun 2017, terlihat pada tabel berikut ini :

Tabel 3 Pengaruh Pemberian Jus Semangka terhadap Penurunan Tekanan Darah pada Lansia Penderita Hipertensi di Wilayah KerjaPuskesmas Lubuk Buaya Padang Tahun 2017

\begin{tabular}{|c|c|c|c|c|c|c|c|}
\hline Kelompok & & & $\mathbf{N}$ & Mean & SD & $\mathbf{T}$ & $\begin{array}{c}P \\
\text { value }\end{array}$ \\
\hline \multirow{4}{*}{ Intervensi } & \multirow{2}{*}{$\begin{array}{l}\text { Pre } \\
\text { test }\end{array}$} & Sistolik & 15 & 174,00 & 7,37 & \multirow{2}{*}{9,00} & \multirow{2}{*}{0,000} \\
\hline & & Diastolik & 15 & 96,67 & 9,76 & & \\
\hline & \multirow{2}{*}{$\begin{array}{l}\text { Pos } \\
\text { test }\end{array}$} & Sistolik & 15 & 156,00 & 5,07 & \multirow{2}{*}{6,81} & \multirow{2}{*}{0,000} \\
\hline & & Diastolik & 15 & 82,00 & 4,14 & & \\
\hline \multirow{4}{*}{ Kontrol } & \multirow{2}{*}{$\begin{array}{l}\text { Pre } \\
\text { test }\end{array}$} & Sistolik & 15 & 169,33 & 9,61 & \multirow{2}{*}{1,38} & \multirow{2}{*}{0,189} \\
\hline & & Diastolik & 15 & 96,67 & 7,23 & & \\
\hline & \multirow{2}{*}{$\begin{array}{l}\text { Pos } \\
\text { test }\end{array}$} & Sistolik & 15 & 167,33 & 7,03 & \multirow{2}{*}{2,09} & \multirow{2}{*}{0,055} \\
\hline & & Diastolik & 15 & 93,33 & 4,88 & & \\
\hline
\end{tabular}

Berdasarkan tabel 3 di atas dapat dilihat bahwa hasil uji paired samples test (uji T-Test) didapatkan $\mathrm{p}$ value $=0,000(\mathrm{p} \leq 0,05)$ yang artinya ada pengaruh pemberian jus semangka terhadap penurunan tekanan darah pada lansia penderita hipertensi di Wilayah Kerja Puskesmas Lubuk Buaya Padang Tahun 2017.

\section{IV.PEMBAHASAN}

\section{A. Analisi Univariat}

\section{Tekanan Darah Lansia sebelum Pemberian Jus Semangka}

Penelitian pengaruh pemberian jus semangka terhadap penurunan tekanan darah lansia penderita hipertensi dilakukan di Wilayah Kerja Puskesmas Lubuk Buaya Padang, yaitu di Kelurahan Parupuak Tabing. Penelitian ini dilakukan terhadap 30 orang responden yang dibagi menjadi dua kelompok, yaitu 15 kelompok intervensi dan 15 kelompok kontrol. Pada kelompok intervensi akan dilakukan perlakuan berupa pemberian jus semangka, sedangkan pada kelompok kontrol tidak ada dilakukan perlakuan, dimana akan dilakukan pengukuran tekanan darah pertama (pretest) kepada kedua kelompok responden sebelum dilakukan intervensi.

Hasil penelitian yang dilakukan oleh peneliti pada pengukuran tekanan darah pertama (pretest), didapatkan pada kelompok intervensi pretest rata-rata tekanan darah sistolik adalah $174,00 \mathrm{mmHg}$ dan tekanan darah diastolik 96,67 $\mathrm{mmHg}$, sedangkan pada kelompok kontrol pretest rata-rata tekanan darah sistolik adalah 169,33 $\mathrm{mmHg}$ dan tekanan darah diastolik 96,67 mmHg. Dapat dilihat tingginya rata-rata tekanan darah sistolik dan diastolik pretest pada kedua kelompok responden.

Hasil penelitian ini sejalan dengan penelitian yang dilakukan oleh Sapardi (2014) tentang pengaruh pemberian jus semangka (cilitrus vulgaris schrad) terhadap penurunan tekanan darah lansia dengan riwayat hipertensi di kota Padang. Didapatkan ratarata tekanan darah sistolik pada lansia penderita hipertensi sebelum diberikan jus semangka adalah $173,57 \mathrm{mmHg}$ dan tekanan darah diastolik 96,79 $\mathrm{mmHg}$.

Hipertensi adalah suatu keadaan dimana seseorang mengalami peningkatan tekanan darah di atas normal yang mengakibatkan angka kesakitan (morbiditas) dan angka kematian (mortalitas). Tekanan darah 140/90 mmHg didasarkan pada dua fase dalam setiap denyut jantung yaitu fase sistolik $140 \mathrm{mmHg}$ menunjukkan fase darah yang sedang dipompa oleh jantung dan fase $90 \mathrm{mmHg}$ menunjukkan fase darah yang kembali ke jantung (Triyanto, 2014)

Hasil penelitian yang dilakukan peneliti, ditemukan umur responden pada kelompok intervensi lebih banyak pada rentang umur 55-60 tahun sebanyak 9 orang $(60,0 \%)$, sedangkan pada kelompok kontrol paling banyak pada rentang umur 61-64 sebanyak 11 orang $(73,3 \%)$. Hasil penelitian ini sejalan dengan penelitian yang dilakukan oleh Kusuma (2014) tentang pengaruh variasi dosis semangka kuning (citrullus vulgaris schard) terhadap tekanan darah lansia di Panti Wredha Bala Keselamatan Bugangan Semarang. Ditemukan penderita hipertensi paling banyak pada rentang umur 60-74 tahun (60\%). Dengan ini membuktikan tekanan darah rentan menyerang usia lanjut yaitu 55 tahun ke atas dan hal ini juga dipengaruhi oleh faktor ketidaktahuan lansia akan pentingnya memeriksakan kesehatan dan mengontrol tekanan darah ke pelayanan kesehatan.

Hasil penelitian yang dilakukan peneliti, ditemukan jenis kelamin responden pada kelompok intervensi lebih banyak perempuan sebanyak 11 orang $(73,3 \%)$ dan pada kelompok kontrol juga lebih banyak perempuan sebanyak 9 orang $(60,0 \%)$. Hasil penelitian ini sejalan dengan penelitian yang dilakukan oleh Kusuma (2014) tentang pengaruh variasi dosis semangka kuning (citrullus vulgaris schard) terhadap tekanan darah lansia di Panti Wredha Bala Keselamatan Bugangan Semarang. Ditemukan penderita hipertensi paling banyak pada perempuan sebanyak (60\%), ini membuktikan bahwa tekanan darah tinggi sangat rentan terhadap lansia wanita dan sering kali dikaitkan dengan perubahan hormon setelah menopause. 
Menurut Pardede (2011) pada premenopause wanita mulai kehilangan sedikit demi sedikit hormon estrogen yang selama ini melindungi pembuluh darah dari kerusakan. Proses ini terus berlanjut dimana hormon estrogen tersebut berubah kuantitasnya sesuai dengan umur wanita secara alami, yang umumnya mulai terjadi pada wanita umur 45-55 tahun. Hipertensi lebih banyak menyerang wanita setelah umur 55 tahun.

Berdasarkan hal ini, maka menurut analisa peneliti terhadap penelitian ini adalah sebelum diberikan intervensi berupa pemberian jus semangka didapatkan tingginya rata-rata tekanan darah sistolik dan diastolik. Pada saat tekanan darah mengalami peningkatan secara kronik, saat inilah seseorang dinyatakan mengalami penyakit tekanan darah tinggi. Tekanan darah tinggi dapat dipengaruhi oleh faktor umur, jenis kelamin, faktor genetik, makanan dan pola kebiasaan sehari-hari. Tekanan darah tinggi sangat banyak terjadi pada usia lanjut, pada penelitian ini tekanan darah tinggi banyak terjadi pada rentang umur 61-64 tahun. Tekanan darah tinggi pada lansia rata-rata diatas $160 / 90 \mathrm{mmHg}$. Hal ini disebabkan karena seiring bertambahnya usia, tekanan darah akan cenderung meningkat. Masalah kesehatan pada usia lanjut berawal dari kemunduran sel-sel tubuh, sehingga fungsi dan daya tahan tubuh menurun serta faktor resiko terhadap penyakit pun meningkat. Kebanyakan lansia jarang menyadari bahwa mereka menderita hipertensi. Lansia baru menyadari bahwa mereka menderita hipertensi setelah ada gejala dan dinyatakan menderita tekanan darah tinggi. Hal ini disebabkan karena faktor ketidaktahuan lansia akan pentingnya memeriksakan kesehatan dan mengontrol tekanan darahnya ke pelayanan kesehatan. Faktor resiko hipertensi lainnya yaitu jenis kelamin, dimana jenis kelamin juga sangat mempengaruhi seseorang menderita hipertensi, hal ini sering dikaitkan dengan menopause, karena wanita pasca menopause beresiko tinggi untuk mengalami hipertensi. Hal ini disebabkan karena pada premenopause wanita mulai kehilangan sedikit demi sedikit hormon estrogen yang selama ini melindungi pembuluh darah dari kerusakan.

\section{Tekanan Darah Lansia sesudah Pemberian Jus Semangka}

Penelitian pengaruh pemberian jus semangka terhadap penurunan tekanan darah lansia penderita hipertensi dilakukan di Wilayah Kerja Puskesmas Lubuk Buaya Padang, yaitu di Kelurahan Parupuak Tabing. Penelitian ini dilakukan terhadap 30 orang responden yang dibagi menjadi dua kelompok, yaitu 15 kelompok intervensi dan 15 kelompok kontrol. Pada kelompok intervensi akan dilakukan perlakuan berupa pemberian jus semangka, sedangkan pada kelompok kontrol tidak ada dilakukan perlakuan, dimana setelah dilakukan intervensi berupa pemberian jus semangka kepada kelompok intervensi selama 7 hari berturut-turut akan dilakukan pengukuran tekanan darah kedua (posttest) kepada kedua kelompok responden.

Hasil penelitian yang dilakukan oleh peneliti pada pengukuran tekanan darah kedua posttest, didapatkan pada kelompok intervensi posttest rata-rata tekanan darah sistolik adalah 156,00 $\mathrm{mmHg}$ dan tekanan darah diastolik $82,00 \mathrm{mmHg}$, sedangkan pada kelompok kontrol posttest rata-rata tekanan darah sistolik adalah $167,33 \mathrm{mmHg}$ dan tekanan darah diastolik 93,33 mmHg. Hal ini sejalan dengan penelitian yang dilakukan oleh Sapardi (2014) tentang pengaruh pemberian jus semangka (cilitrus vulgaris schrad) terhadap penurunan tekanan darah lansia dengan riwayat hipertensi di kota Padang. Didapatkan tekanan darah sistolik pada lansia penderita hipertensi sesudah diberikan jus semangka adalah 142,07 $\mathrm{mmHg}$ dan tekanan darah diastolik 90,14 mmHg. Hal ini membuktikan bahwa pemberian jus semangka dapat menurunkan tekanan darah pada lansia penderita hipertensi. Hal ini dapat dilihat dari hasil penelitian, dimana terdapat perbedaan tekanan darah pada kelompok intervensi yang diberi perlakuan dengan kelompok kontrol tanpa perlakuan. Pada kelompok intervensi terjadi penurunan tekanan darah, sedangkan pada kelompok kontrol tidak terjadi penurunan tekanan darah.

Semangka merupakan buah yang memiliki manfaat luar biasa untuk kesehatan. Semangka memiliki kulit cukup tebal, berwarna hijau muda dengan larik-larik hijau tua, dan daging buah berwarna merah atau kuning. Semangka merupakan salah satu buah favorit bagi hampir seluruh masyarakat Indonesia (Prabantini, 2013).

Hasil penelitian yang dilakukan oleh Arturo (2012) tentang watermelon extract supplementation reduces ankle blood pressure and carotid augmentation index in obese adults with prehypertension or hypertension, yang menyatakan bahwa jus semangka dapat menurunkan tekanan darah disebabkan dari kandungan semangka yang disebut L-citiruline dan L-argine, zat ini mampu merangsang produksi senyawa kimia yang membantu pembuluh darah menjadi lentur dan rileks. Citrulline akan bereaksi jika dikonsumsi dalam jumlah cukup banyak. Zat ini kemudian berubah menjadi arginine, sejenis asam amino yang berkhasiat bagi jantung dan sistem peredaran darah dan kekebalan tubuh yang terbukti menurunkan tekanan darah penderita hipertensi dengan obesitas. Penelitian ini menunjukkan bahwa semangka dapat menurunkan tekanan darah penderita hipertensi $10-20 \mathrm{mmHg}$ pada sistolik maupun diastolik.

Hasil penelitian ini sejalan dengan penelitian yang dilakukan oleh Kusuma (2014) menunjukan bahwa 7 hari setelah pemberian jus semangka tampak sampel mengalami penurunan tekanan darah sistolik, rata-rata 2,66 $\mathrm{mmHg}$ dan tekanan darah diastolik rata-rata $2 \mathrm{mmHg}$. Kondisi tersebut sejalan dengan 
penelitian Nurlina (2011) yang menyatakan bahwa rata-rata tekanan darah sampel sesudah minum jus semangka lebih rendah dibanding sebelum minum jus semangka.

Berdasarkan hal ini, maka menurut analisa peneliti terhadap penelitian ini adalah terbukti bahwa pemberian jus semangka dapat menurunkan tekanan darah pada lansia penderita hipertensi. Hal ini dapat dilihat dari hasil penelitian yang menunjukkan bahwa tekanan darah pada kelompok intervensi yang diberi perlakuan mengalami penurunan tekanan darah, sedangkan tekanan darah pada kelompok kontrol tanpa perlakuan tidak terjadi penurunan tekanan darah. Dari hasil penelitian ini juga didapat bahwa mengkonsumsi obat herbal jauh lebih baik karena memiliki khasiat yang sangat banyak, harga murah dan mudah didapat serta memiliki efek samping yang sangat sedikit. Oleh karena itu, sangat bagus menerapkan pengobatan herbal untuk menyembuhkan berbagai penyakit karena sangat banyak manfaatnya serta memiliki nilai lebih baik untuk kesehatan kita sendiri. Semangka merupakan salah satu buah-buahan yang dapat digunakan sebagai obat herbal untuk menurunkan tekanan darah, karena kandungan yang ada dalam obat anti hipertensi tersebut ada beberapa yang kita temui dalam semangka yaitu potassium, beta karoten dan kalium. Semangka juga sangat kaya akan kandungan air, asam amino, L-arginine yang dapat menjaga tekanan darah yang sehat. Semangka juga dapat menetralkan tekanan darah, sehingga semangka aman dikonsumsi tanpa rasa khawatir akan membuat drop tekanan darah.

\section{B. ANALISA BIVARIAT}

Berdasarkan hasil penelitian pada kelompok intervensi dapat disimpulkan bahwa tekanan darah sistolik rata-rata sebelum pemberian jus semangka adalah $174,00 \mathrm{mmHg}$ dengan standar deviasi 7,368. Setelah dilakukan pemberian jus semangka selama 7 hari berturut-turut terjadi penurunan tekanan darah sistolik menjadi $156,00 \mathrm{mmHg}$ dengan standar deviasi 5,071. Pada tekanan darah diastolik rata-rata sebelum pemberian jus semangka adalah 96,67 mmHg dengan standar deviasi 9,759. Setelah dilakukan pemberian jus semangka selama 7 hari berturut-turut terjadi penurunan tekanan darah diastolik menjadi 82,00 dengan standar deviasi 4,140. Hasil uji paired samples test (uji T-Test) didapatkan $\mathrm{p}$ value $=0,000(\mathrm{p} \leq 0,05)$ yang artinya bahwa ada pengaruh pemberian jus semangka terhadap penurunan tekanan darah pada lansia penderita hipertensi di Wilayah Kerja Puskesmas Lubuk Buaya Padang Tahun 2017.

Pada prinsipnya ada dua macam terapi yang bisa dilakukan untuk mengobati penyakit hipertensi, yaitu terapi farmakologi dengan menggunakan obat dan terapi non farmakologi yaitu dengan modifikasi pola hidup sehari-hari dan kembali ke produk alami (back to nature). Mengacu pada konsep back to nature yaitu dengan menggunakan bahan lokal seperti semangka yang banyak terdapat di masyarakat, karena bahan tersebut kaya akan kalium dapat menurunkan tekanan darah penderita hipertensi (Bangun, 2013).

Menurut Nisa (2011) peranan mineral natrium dan kalium berfungsi menjaga keseimbangan tekanan darah dalam tubuh. Kedua mineral ini bekerja secara berlawanan, singkatnya natrium menaikkan tekanan darah sedangkan kalium menurunkan tekanan darah. Oleh karena itu, asupan natrium dan kalium haruslah seimbang supaya tubuh tetap sehat.

Semangka kaya akan kalium. Kandungan kalium dalam semangka sebesar $112 \mathrm{mg}$ sehingga, mereka yang menderita hipertensi disarankan untuk mengkonsumsi semangka. Semangka yang bersifat uretic memiliki kandungan air yang tinggi juga berfungsi sebagai pelarut dan pembawa sampah hasil sisa metabolisme sehingga natrium dapat dikeluarkan melalui urine (Olivia, 2014).

Hasil penelitian ini sejalan dengan penelitian yang dilakukan oleh Sapardi (2014) tentang pengaruh pemberian jus semangka (cilitrus vulgaris schrad) terhadap penurunan tekanan darah lansia dengan riwayat hipertensi di kota Padang. Hasil penelitian Sapardi menunjukkan bahwa rata-rata tekanan darah sistolik dan diastolik sesudah diberikan jus semangka 142,07/90,14 mmHg lebih rendah dibandingkan dengan tekanan darah rata-rata tekanan darah sistolik dan diastolik sebelum diberikan jus semangka 173,57/96,79 $\mathrm{mmHg}$. Hasil uji statistik menunjukkan nilai p value $=0,000$ maka dapat disimpulkan adanya perbedaan bermakna antara tekanan darah sistolik dan diastolik sebelum dan sesudah pemberian jus semangka.

Hasil penelitian yang dilakukan oleh Widodo (2015) tentang the effects of consume watermelon juice in changes blood pressure hypertension patients with obesity in srimulyo village region of local government clinic Piyungan Bantul Yogyakarta ditemukan hasil nilai sistolik $\mathrm{z}$ hitung $-3,174$ dengan $p$ value $=0,000$ dan nilai diastolik $-3,275$ dengan $p$ value $=0,001$. Dari hasil penelitian tersebut dapat disimpulkan adanya pengaruh mengkonsumsi jus semangka terhadap penurunan tekanan darah penderita hipertensi dengan obesitas.

Hasil penelitian yang dilakukan oleh Kusuma(2014) tentang pengaruh variasi dosis semangka kuning (citrullus vulgaris schrad) terhadap tekanan darah lansia di Panti Wredha Bala Keselamatan Bugangan Semarang ditemukan hasil tekanan darah diastolik sebelum dan sesudah perlakuan menunjukan perbedaan yang signifikan pada ketiga perlakuan ( $\mathrm{p}$ value $\leq 0,05$ ). Penurunan tekanan darah diastolik terbesar terjadi pada perlakuan pemberian semangka kuning dengan dosis $250 \mathrm{mg}$. Hasil t-test pada rata-rata penurunan tekanan darah diastolik menunjukan $\mathrm{p}$ value $=0,009$. Dari hasil penelitian tersebut dapat disimpulkan adanya 
pengaruh variasi pemberian dosis semangka kuning terhadap penurunan tekanan darah.

Hal ini sesuai dengan pendapat Paramitha (2012) bahwa semangka sangat baik bagi pengidap hipertensi. Kandungan air, magnesium dan kaliumnya yang tinggi bisa menetralisasi dan menurunkan tekanan darah. Selain itu, adanya karatenoid di dalamnya juga dapat mencegah pengerasan pada dinding arteri maupun pembuluh darah vena, sehingga dapat membantu mengurangi tekanan darah. Semangka kaya akan kalium. Kandungan kalium di dalam semangka sebesar 112 mg sehingga mereka yang menderita hipertensi disarankan untuk mengkonsumsi semangka. semangka yang bersifat uretic memiliki kandungan air yang tinggi juga berfungsi sebagai pelarut dan pembawa sampah hasil sisa metabolisme sehingga natrium dapat dikeluarkan melalui urine (Olivia, 2014).

Berdasarkan hal ini, maka analisa peneliti terhadap penelitian ini adalah penelitian yang telah peneliti lakukan selama 7 hari berturut-turut didapatkan hasil yang sangat bermakna, dimana didapatkan penurunan tekanan darah sistolik dan diastolik pada lansia penderita di Wilayah Kerja Puskesmas Lubuk Buaya Padang. Dengan adanya penurunan tekanan darah ini membuktikan bahwa kandungan yang ada di dalam semangka dapat menurunkan tekanan darah secara perlahan tanpa efek samping yang merugikan orang yang mengkonsumsinya. Selain menurunkan tekanan darah, semangka juga dapat menetralkan tekanan darah sehingga pengkonsumsi jus semangka tidak akan mengalami penurunan tekanan darah secara terus menerus, sehingga akan aman dikonsumsi tanpa rasa khawatir akan membuat drop tekanan darah, artinya tekanan darah akan tetap stabil.

Pengkonsumsian jus semangka secara teratur dapat menurunkan tekanan darah, ini terbukti dari penurunan tekanan darah responden yang mengkonsumsi jus semangka selama 7 hari berturutturut, hal ini dapat dilihat pada gambar 4.1 dan 4.2 dimana pada kelompok intervensi terjadi penurunan tekanan darah sistolik dan diastolik setiap harinya, sedangkan pada kelompok kontrol pada hari ke-5 terjadi peningkatan tekanan darah sistolik dan pada hari ke-3 dan ke-7 terjadi peningkatan tekanan darah diastolik. Hal ini disebabkan oleh faktor lain, seperti responden mengkonsumsi makanan yang mengandung lemak dan santan serta bisa juga disebabkan oleh stress. Pengalaman yang peneliti dapatkan di lapangan selama penelitian, penurunan tekanan darah dengan mengkonsumsi jus semangka ini lebih terlihat jelas secara teratur apabila responden atau individu tersebut menghindari makanan yang berlemak dan bersantan seperti rendang. Dukungan keluarga pun sangat membantu untuk kepatuhan dan keteraturan meminum jus semangka untuk menurunkan tekanan darah responden itu sendiri. Dengan mengkonsumsi jus semangka dapat merangsang pengeluaran urine karena semangka banyak mengandung air sehingga kadar natrium yang berlebih dalam tubuh dapat dikeluarkan melalui urine, sedangkan kandungan kalium yang cukup tinggi dalam semangka dapat membantu kerja jantung dan menormalkan tekanan darah serta menjaga tekanan darah agar tetap normal.

\section{KESIMPULAN}

Setelah dilakukan penelitian tentang pengaruh pemberian jus semangka terhadap penurunan tekanan darah pada lansia penderita hipertensi di wilayah kerja Puskesmas Lubuk Buaya Padang Tahun 2017, maka dapat disimpulkan :

1. Rata-rata tekanan darah sistolik pada lansia sebelum diberikan jus semangka pada kelompok intervensi adalah $174,00 \mathrm{mmHg}$ dan rata-rata tekanan darah diastolik adalah 96,67 $\mathrm{mmHg}$, sedangkan pada kelompok kontrol rata-rata tekanan darah sistolik sebelum diberikan jus semangka adalah $169,33 \mathrm{mmHg}$ dan tekanan darah diastolik adalah $96,67 \mathrm{mmHg}$.

2. Rata-rata tekanan darah sistolik pada lansia sesudah diberikan jus semangka pada kelompok intervensi adalah 156,00 $\mathrm{mmHg}$ dan tekanan darah diastolik adalah $82,00 \mathrm{mmHg}$, sedangkan pada kelompok kontrol rata-rata tekanan darah sistolik sesudah diberikan jus semangka adalah $167,33 \mathrm{mmHg}$ dan tekanan darah diastolik adalah 93,33 $\mathrm{mmHg}$.

3. Ada pengaruh pemberian jus semangka terhadap penurunan tekanan darah pada lansia penderita hipertensi di Wilayah Kerja Puskesmas Lubuk Buaya Padang Tahun 2017 dengan p value= 0,000 .

Disarankan kepada pihak Puskesmas Lubuk Buaya Padang untuk meningkatkan pengetahuan masyarakat dengan cara penyuluhan salah satunya agar masyarakat lebih menyadari bahaya akibat hipertensi dan pentingnya pengobatan sedini mungkin dengan tidak mengeluarkan biaya yang tinggi dengan memanfaatkan buah semangka sebagai pengobatan herbal.

\section{Daftar Pustaka}

[1] Anonim. 2013.2 Hipertensi. (http://yienmail.wordpress.com di akses 27 Mei 2017, jam 17.00 WIB)

[2] Arturo. 2012. Turunkan Hipertensi dengan Semangka. (http://yienmail.wordpress.com di akses 28 Mei 2017, jam 11.30 WIB)

[3] Badan Kependudukan dan Keluarga Berencana Nasional. 2015. Pelayanan dan Peningkatan Kesehatan Usia Lanjut. 
(www.depkes.go.id di akses 27 Mei 2017, jam 13.00 WIB)

[4] Badan Pusat Statistik. 2014. Statistik Penduduk Lanjut Usia. (www.bappenas.go.id. di akses 26 Mei 2017, jam 14.30 WIB)

[5] Bangun, A.P. 2013. Khasiat Tanaman Obat untuk Hipertensi. Jakarta: Sarana Pustaka Prima

[6] Dinas Kesehatan Kota Padang. 2016. Profil Kesehatan Kota Padang. Padang: Dinkes

[7] Kemenkes RI. 2015. Infodatin Lansia. (www.depkes.go.id di akses 26 Mei 2017, jam 19.00 WIB)

[8] Kusuma, S.H., Bintanah, S., \& Caturwati, I. 2014. Pengaruh Variasi Dosis Semangka Kuning (Citrullus Vulgaris Schard) terhadap Tekanan Darah Lansia di Panti Wredha Bala Keselamatan Bugangan Semarang (skripsi). Semarang: Universitas Muhammadiyah

[9] Maryam. S. 2011. Mengenal Usia Lanjut dan Perawatannya. Jakarta: Salemba Medika

[10] Nisa, I. 2012. Ajaibnya Terapi Herbal Tumpas Penyakit Darah Tinggi. Jakarta: Dunia Sehat

[11] Nugroho. W. 2014. Keperawatan Gerontik dan Geriatrik. Jakarta: EGC

[12] Olivia. 2014.S emangka Kaya akan Kalium. $\quad$ (http: //www.rumahsehat.blogspot.com/2017/11/ma nfaat-buah semangka. di akses tanggal 10 Februari 2017, jam 16.30 WIB)

[13] Paramitha. S. 2012. Sehat dan Bugar dengan Terapi Jus Buah dan Sayur. Yogyakarta: Lintas Media

[14] Pardede, T.R. 2011.Penetapan Kadar Kalium, Natrium dan Magnesium pada Semangka Daging Buah Berwarna Kuning dan Merah secara Spektrofotometri Serapan Atom. Medan: Universitas Sumatera Utara

[15] Prabantini. D. 2013. Makanan dengan Kekuatan Dahsyat Menangkal Kanker. Yogyakarta: Andi Offset

[16] Profil Puskesmas Lubuk Buaya Padang. 2016.

[17] Purwanto, B. 2014. Buku Ajar Ilmu Keperawatan Berbasis Herbal. Yogyakarta: D-Medika

[18] Puspaningtyas. D.E. 2013. The Miracle of Fruits. Jakarta: Agromedia Pustaka

[19] Riskesdas. 2013. Hipertensi di Indonesia. (www.depkes.go.id. di akses tanggal 5 Februari 2017, jam 15.00 WIB)

[20] Sapardi, V.S., \& Fridalni, N. 2014. Pengaruh Pemberian Jus Semangka (Cilitrus Vulgaris Schrad) terhadap Penurunan Tekanan Darah Lansia dengan Riwayat Hipertensi di Kota Padang (skripsi). Padang: STIKes Mercu Bakti Jaya

[21] Triyanto. E. 2014. Pelayanan Keperawatan bagi Penderita Hipertensi secara Terpadu. Yogyakarta: Graha Ilmu

[22] WHO. 2013. World Health Day 2013:Measure Your Blood Pressure, Reduce Your Risk. (http://www.who.int. diakses tanggal 12 Februari 2017, jam 17.00 WIB)

[23] Widodo, A., \& Sutanta. 2015. The Effects of Consume Watermelon Juice in Changes Blood Pressure Hypertension Patients with Obesity in Srimulyo Village Region of Local Government Clinic Piyungan Bantul Yogyakarta. 06(01), 84-85 